\title{
Effect of photoperiod on LH, FSH and prolactin patterns in ovariectomized oestradiol-treated heifers*
}

\author{
J. K. Critser§, M. J. Lindstrom†, M. M. Hinshelwood and E. R Hauser \\ Department of Meat and Animal Science, and $\dagger$ Department of Statistics, \\ University of Wisconsin-Madison, Madison, WI 53706, U.S.A.
}

\begin{abstract}
Summary. Angus and Angus crossbred heifers were ovariectomized, treated with oestradiol implants and randomly assigned to (1) the natural photoperiod of fall to spring for $43^{\circ} \mathrm{N}$ latitude or (2) extra light simulating the photoperiod of spring to fall. Weekly blood samples were taken for 6 months (fall to spring equinox). All heifers were cannulated every 4 weeks and blood samples were taken for $4 \mathrm{~h}$ at 15 -min intervals. Sera were assayed for LH, FSH, prolactin and oestradiol. In samples taken weekly, serum LH and FSH concentrations were higher while serum prolactin was lower in heifers exposed to natural photoperiod. There was a photoperiod $\times$ time interaction for both FSH and prolactin with concentrations diverging as photoperiod diverged. Circulating concentrations of oestradiol were not different between groups. In samples taken every 4 weeks at 15-min intervals, baseline concentrations of LH and FSH and LH pulse amplitude were higher while prolactin pulse frequency was lower in heifers exposed to natural photoperiod. There was a photoperiod $\times$ time interaction for each of these pulsatile characteristics. The correlation between $\mathrm{LH}$ and prolactin concentrations estimated from the 15 -min samples differed between the two photoperiod treatment groups. The pooled correlation coefficient $(r)$ was $-0 \cdot 12$ under natural photoperiod and +0.50 under extra light. There was also a photoperiod $\times$ time interaction with negative correlations occurring when photoperiod was decreasing and positive correlations occurring when photoperiod was increasing. These results support the hypothesis that photoperiod alters serum concentrations of LH, FSH and prolactin in cattle.
\end{abstract}

\section{Introduction}

Many studies of cattle have reported a seasonal influence on reproduction (Mercier \& Salisbury, 1947; Ortavant et al., 1964; Salisbury et al., 1978; Tucker \& Oxender, 1980; Hauser, 1984; McNatty et al., 1984), although more subtle than in other domestic ruminants (e.g. sheep and goats). Most investigators agree that a seasonal influence exists, but disagree as to the cause. Photoperiod, temperature, humidity, level of nutrition, management or a combination of these have been proposed as causal factors (Salisbury et al., 1978). Although cows cycle and breed throughout the year, there appear to be seasonal influences on certain events associated with reproductive performance. Heifer calves born in the spring achieve puberty at younger ages than those born in the fall (Hawk et al., 1954; Roy et al., 1980). Prepubertal heifers exposed to long photoperiod or spring to fall patterns of photoperiod and temperature achieve puberty at earlier ages than do heifers exposed to short photoperiod or fall to spring patterns of photoperiod and temperature (Peters \& Tucker, 1978;

\footnotetext{
*Reprint requests to Dr E. R. Hauser.

§resent address: Department of Biochemistry and Molecular Biology, The Mayo Clinic, Mayo Foundation, Rochester, MN 55905, U.S.A.
} 
Schillo et al., 1983b; Hansen et al., 1983). Heifers born in the fall have shorter oestrous cycles after becoming pubertal than do those born in the spring or summer (Mares et al., 1961). Postpartum anoestrous periods were shortest during late spring and early summer and longest during fall and winter (Warnick, 1955; Thibault et al., 1966; Bulman \& Lamming, 1978; Peters \& Riley, 1982) and may be shortened in winter by exposure to long photoperiod (Hansen \& Hauser, 1983). Conception rates were higher from fall to spring than from spring to fall (Thibault et al., 1966; Courot et al., 1968). Follicular growth was greater in winter and spring in comparison with fall as determined by a greater number of both normal and atretic follicles (Rajakowski, 1960). In another study, a greater diameter and number of granulosa cells for large healthy follicles and the dominant oestrogen-secreting follicles were found in winter compared to spring (McNatty et al., 1984). Hypophysial secretion of gonadotrophins may have been higher in those seasons than at others.

Critser et al. (1983) reported a seasonal pattern in circulating serum LH concentrations in ovariectomized heifers, with highest values in winter and lowest levels in summer. The present experiment was designed to test the hypotheses that (1) short photoperiod increases serum LH and FSH concentrations, and decreases serum prolactin concentrations, in ovariectomized oestradioltreated heifers and (2) photoperiod influences pulse frequencies, pulse amplitudes, pulse durations or basal secretion values of these hormones.

\section{Materials and Methods}

\section{Experimental animals}

Eight cyclic Angus and Angus crossbred heifers were ovariectomized between 26 and 28 August 1981. On 11 September all heifers received oestradiol-17ß (Sigma Chemical Company, St Louis, MO, U.S.A.) in three subcutaneous implants $(50 \mathrm{~mm} \times 3.35 \mathrm{~mm}$ (i.d.), $4.65 \mathrm{~mm}$ (o.d.)) of Silastic tubing (Dow Corning Corporation, Midland, MI, U.S.A.) estimated to maintain serum oestradiol concentrations at $15 \mathrm{pg} / \mathrm{ml}$ (Beck et al., 1976). Oestradiol-17 $\beta$ administered in this manner elevates circulating concentrations of LH (Critser et al., 1983).

Experimental design. At the autumnal equinox, heifers were randomly assigned to one of two photoperiod treatments. Four were housed in an open shed with access to an outside yard and exposed to the natural photoperiod of fall to spring for $43^{\circ} \mathrm{N}$ latitude. The other 4 were housed in a similar open shed equipped with fluorescent lights regulated by automatic timers to provide extra light simulating the photoperiodic patterns from the vernal equinox to the autumnal equinox (Fig. 1). Light intensity during 'lights on' averaged 470 lux at approximately the height of the heifer's eyes. Photoperiod changes in the extra lighting group were made at weekly intervals. At 09:00 h each day all heifers were let out into an outside yard and at $15: 00 \mathrm{~h}$ each day all heifers were confined inside their respective sheds to ensure that the animals would be exposed to the assigned photoperiod after sunset. All heifers were fed the same diet which consisted of hay ad libitum.

Blood sampling. Weekly blood samples were taken by jugular venepuncture at about 11:00 h. Every 4 weeks for 26 weeks animals were fitted with indwelling jugular cannulae and blood samples taken every $15 \mathrm{~min}$ for $4 \mathrm{~h}(11: 00 \mathrm{~h}$ to 15:00 h) (Fig. 1). Blood was allowed to clot overnight, centrifuged, sera decanted and stored at $-20^{\circ} \mathrm{C}$ until assayed for $\mathrm{LH}, \mathrm{FSH}$, prolactin and oestradiol.

\section{Hormone assays}

The sensitivity of the assays was defined as $90 \%$ maximal binding $\left(\mathrm{B}_{\mathrm{o}}\right)$; the intra- and interassay coefficients of variation were calculated from standard curves and quality control samples of different volumes of a sera pool from ovariectomized heifers run in quadruplicate in 7 assays (Baxter, 1980). All samples for all hormone determinations were assayed in duplicate and all samples from an animal were run in the same assay. An antirabbit gamma globulin serum fraction prepared in sheep was used as second antibody for all protein assays.

$L H$. Serum LH concentrations were determined using the RIA developed by Niswender et al. (1969), and validated in our laboratory (Schillo et al., 1983a). Concentrations of LH were expressed in terms of NIAMDD-bLH-4 standard. A serum pool from ovariectomized heifers produced a slope not significantly different $(P>0 \cdot 10)$ from the standard curve when run at volumes between 50 and $400 \mu \mathrm{l}$. The intra-assay and interassay coefficients of variation were $9 \cdot 5 \%$ and $13.6 \%$, respectively. Mean ( \pm s.e.m.) binding was $28 \pm 0.1 \%$ and the mean ( \pm s.e.m.) lower limit of sensitivity was $0.06 \pm 0.004 \mathrm{ng} /$ tube.

FSH. Serum FSH concentrations were determined using the RIA developed by Bolt \& Rollins (1983), previously validated in our laboratory (Hansen et al., 1982). Serum pools from bulls and ovariectomized animals inhibited 


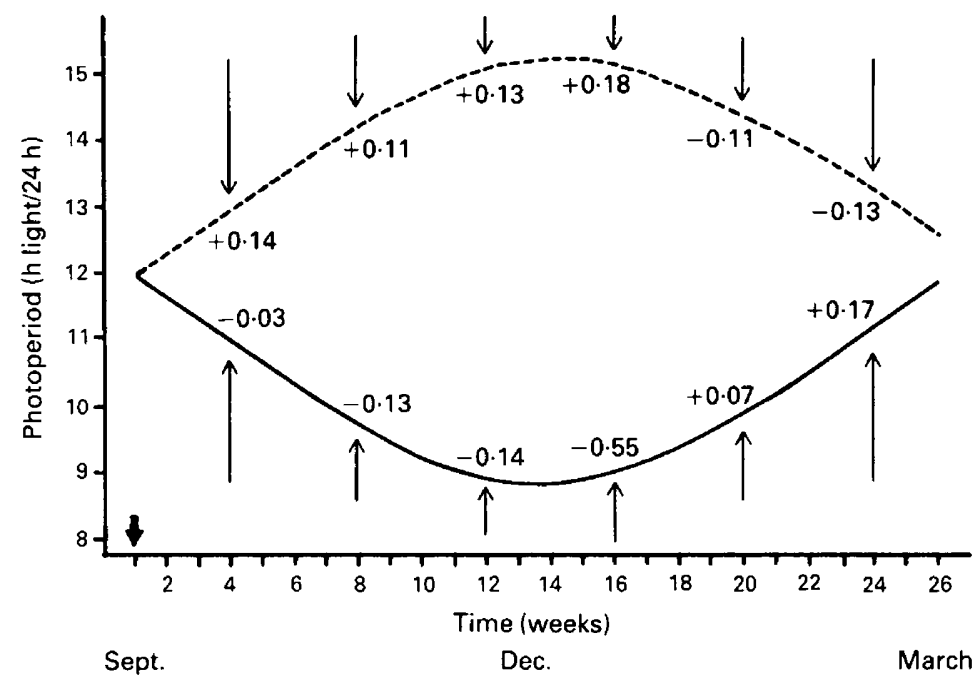

Fig. 1. Hours of light per 24-h period for natural photoperiod (-) and extra light (--) treatment groups. Animals in the extra light group were exposed to weekly changes in the number of hours of light $/ 24 \mathrm{~h}$; while animals in the natural photoperiod group were exposed to daily changes. Arrows represent the times of frequent blood sampling and the pooled correlation coefficients (Spearman's rank correlation) at these times for the relationship between LH and prolactin concentrations are shown.

binding such that their slopes were not significantly different $(P>0 \cdot 10)$ from the standard curve when assayed at volumes of $50-400 \mu$. The intra-assay and interassay coefficients of variation were $8 \%$ and $12 \%$, respectively. Mean ( \pm s.e.m.) binding was $16.9 \pm 0.1 \%$ and the mean ( \pm s.e.m.) lower limit of sensitivity was $0.34 \pm 0.001 \mathrm{ng} /$ tube.

Prolactin. Serum prolactin concentrations were determined using the RIA developed by Forrest et al. (1980), and validated in our laboratory (Schillo et al., 1983b). Serum pools from pregnant cows or ovariectomized heifers inhibited binding such that these slopes were not significantly different from the standard curve when run at volumes of $10-50 \mu 1$. The intra-assay and interassay coefficients of variation were $7.8 \%$ and $12.6 \%$, respectively. Mean ( \pm s.e.m.) binding was $40.7 \pm 6.7 \%$ and the mean $( \pm$ s.e.m.) lower limit of sensitivity was $0.09 \pm 0.005 \mathrm{ng} /$ tube. Stress has been shown to affect prolactin concentrations (Rand et al., 1971). Circulating concentrations of prolactin were higher in serum obtained by cannulation than in that collected by venepuncture $(P=0.001)$, as has also been reported by Jöhke (1970). Therefore, 14-day rather than 7-day samples were used to characterize photoperiod effects.

Oestradiol-17ß. Serum oestradiol was determined using the RIA described by Sislow et al. (1979), previously validated in our laboratory (Hinshelwood et al., 1985). Serum pools from ovariectomized heifers and bulls to which oestradiol was added inhibited binding (after extraction and reconstitution) and the slopes were linear and not significantly different $(P>0 \cdot 10)$ from the standard curve in volumes of $100-400 \mu l$ (heifers). Percentage cross-reactivities of the antiserum with oestriol, oestrone and oestradiol- $17 \alpha$ standard $(40-120 \mathrm{pg}$ ) were $5 \cdot 4 \%, 3 \cdot 2 \%$ and $1 \cdot 6 \%$, respectively. Mean ( \pm s.e.m.) recovery was $91.4 \pm 0.1 \%$ and the mean lower limit of sensitivity corrected for recovery was $2.8 \mathrm{pg} / \mathrm{tube}$. All samples were run in a single assay and the interassay coefficient of variation was $6.8 \%$.

\section{Statistical analysis}

The data consist of multiple measurements taken over time on each animal and require statistical analyses that take into account possible correlation over time (Gill \& Hafs, 1971; O'Sullivan et al., 1984). There is no generally accepted method for analysis when biologically important interactions are expected. Accordingly, these data were analysed using a combination of techniques including split-plot ANOVA, Hotelling's $\mathrm{T}^{2}$-tests, polynomial contrasts and one-sided T-tests. Because of the large number of non-independent measurements taken on the frequent samples, the tests should be viewed as exploratory.

Weekly samples. The data from the weekly blood samples were analysed using a split-plot ANOVA with heifers as 'whole plots' and time within heifers as 'subplots'. The effect of treatment was divided into the main effect of photoperiod and the interaction between photoperiod and time. The existence of this interaction was deduced as photoperiod changed over time in such a way as to begin and end with the same photoperiodic exposure. Split-plot analysis is valid for testing the main effect of treatment, but it is not valid for testing time effects or the photoperiod $\times$ time interaction 
unless the observations are independent or correlated uniformly over time (Gill \& Hafs, 1971). For these data the problem was minimized by analysing the low order polynominal (linear, quadratic, cubic) contrasts over time. These contrasts were less correlated than the original data and are biologically meaningful.

The direction of the main effect of photoperiod and quadratic time $\times$ photoperiod interactions were expected before the start of the experiment and one-sided T-tests were used.

Frequent (15-min samples). The 'Pulsar' program developed by Merriam \& Wachter (1982) was used in the analysis of the $\mathrm{LH}, \mathrm{FSH}$ and prolactin data from the samples taken at 15 -min intervals. This program was designed to identify peaks by calculating a 'smoothed baseline' using a robust locally weighed regression (Cleveland, 1979), subtracting the actual hormone value from this baseline, and scaling the residual using an intra-assay standard deviation calculated for each hormone (Baxter, 1980). The program then recalculated each of the steps excluding values designated as significant deviations from the baseline (peaks). The recalculations were repeated up to 6 times until two consecutive iterations produce the same peak identification.

The program requires that two criteria be determined for each data set. The first is 'smoothing time', the number of time points over which the robust regression 'smooth baseline' is calculated. In this project this 'smooth time' was $2 \mathrm{~h}$ (8 sample points) for LH and FSH and $1.5 \mathrm{~h}$ ( 6 sample points) for prolactin. The second criterion was the "cut off' value, the number of standard deviations a value must be above the 'baseline' to be identified as a peak. The program was carried further in that it was possible to have multiple consecutive points identified as peaks if they.were some lesser number of standard deviations above the 'baseline'. The criteria used for these data were 2.0 standard deviations (s.d.) for single point, 1.8 s.d. for two consecutive points and 1.6 s.d. for three consecutive points. As other studies have reported (Rasmussen \& Malven, 1983), this program produces conservative peak identification when compared to other methods.

Four pulsatile attributes were measured for each heifer at each cannulation for each hormone: (1) pulse frequency (no. of pulses $/ 4 \mathrm{~h}$ ), (2) mean peak amplitude (maximal value if more than a single time point within a pulse), (3) mean peak duration ( $\mathrm{min}$ ) and (4) mean basal secretion (estimated from the robust regression).

The temporal correlation between LH and prolactin was estimated for each heifer at each cannulation using a Spearman's rank correlation (Snedecor \& Cochran, 1979). The four attributes mentioned above and the Spearman's rank correlation coefficients were analysed using split-plot ANOVA. In this case an exact Hotelling's $\mathbf{T}^{2}$-test was possible and confirmed the split plot analysis.

\section{Results}

Weekly samples

$L H$. Serum concentrations of LH were higher $(P=0.03)$ in heifers exposed to natural photoperiod than those exposed to extra light $(3.20 \pm 0.50 \mathrm{vs} 1.60 \pm 0.30 \mathrm{ng} / \mathrm{ml}$; mean \pm s.e.m. $)$ (Fig. 2a). There was a quadratic effect of time $(P=0.03)$ and a tendency for a quadratic interaction between photoperiod and time $(P=0 \cdot 12)$, with LH concentrations diverging as photoperiod diverged.

FSH. Circulating concentrations of FSH were greater in heifers exposed to natural photoperiod than those receiving extra light $(P=0.08)(11.00 \pm 0.23 \mathrm{vs} 7.54 \pm 0.23 \mathrm{ng} / \mathrm{ml})(\mathrm{Fig} .2 \mathrm{~b})$. There was a quadratic photoperiod $\times$ time interaction $(P=0.05)$. Circulating FSH concentrations in the natural photoperiod group increased then decreased while those in the extra light group decreased then increased.

Prolactin. The prolactin patterns were reciprocal to those for $\mathrm{LH}$ and FSH. The concentrations of prolactin were lower in the natural photoperiod group than in the extra light group $(P=0.088)$ $(16.50 \pm 8.87$ vs $32.30 \pm 15.92 \mathrm{ng} / \mathrm{ml}$ ) (Fig. 2c). There was a quadratic photoperiod $\times$ time interaction $(P=0.015)$; heifers in both groups had prolactin concentrations which decreased then increased, but separated during the period of most divergent photoperiod. There was also a cubic photoperiod $\times$ time interaction $(P=0.016)$ and a quadratic effect of time $(P=0.002)$.

\section{Frequent samples}

Oestradiol. Circulating concentrations of oestradiol were not different $(P=0.078)$ between groups; $7 \cdot 1 \pm 0.9 \mathrm{pg} / \mathrm{ml}$ for heifers exposed to natural photoperiod versus $8 \cdot 3 \pm 2.4$ for those exposed to extra light. 

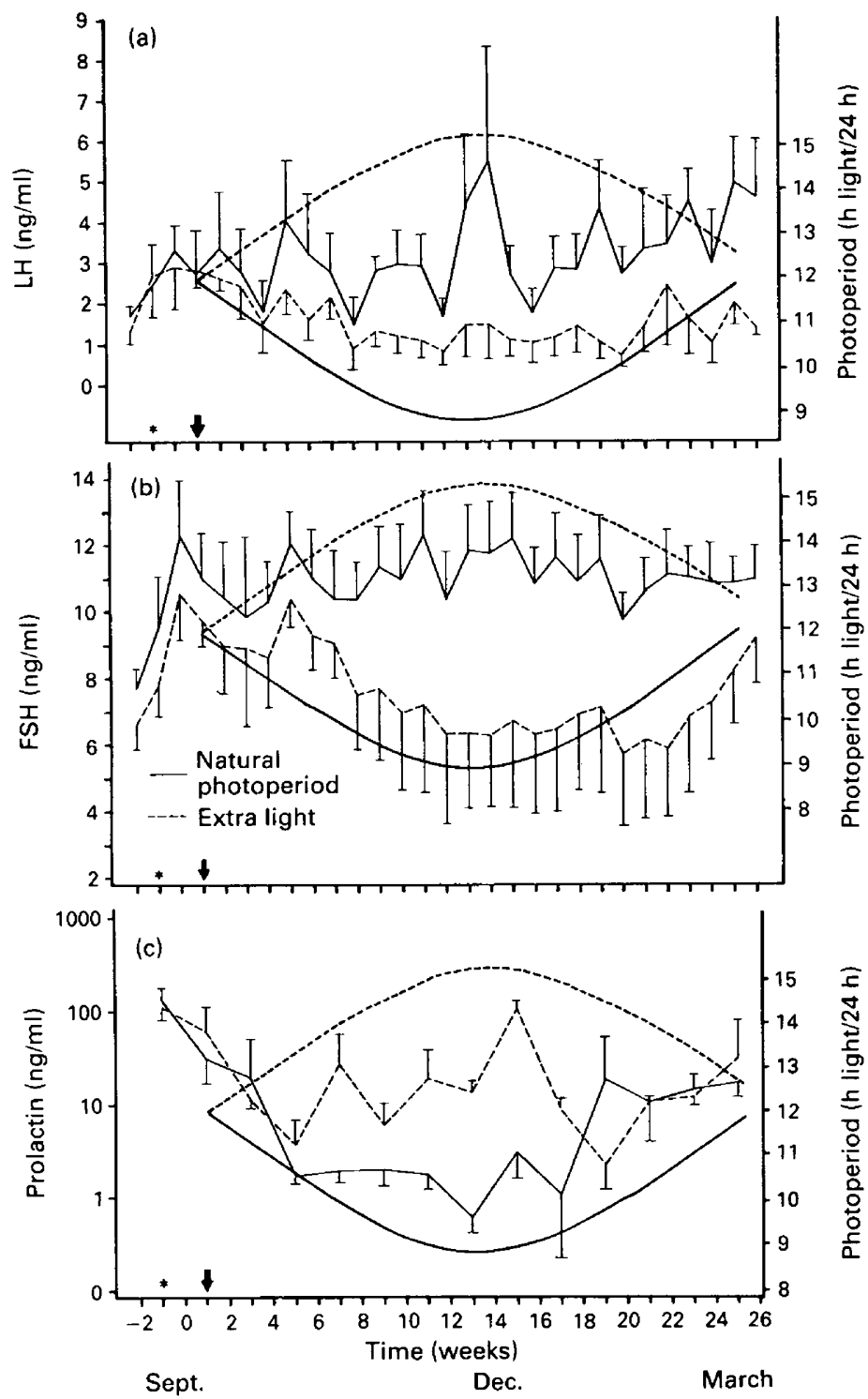

Fig. 2. Effect of photoperiod on mean ( \pm s.e.m.) circulating concentratioins of (a) LH, (b) FSH and (c) prolactin in ovariectomized heifers with oestradiol implants. Values plotted are means of weekly ( $\mathrm{LH}$ and FSH) or fortnightly (prolactin) samples $(\mathrm{N}=4)$. Heifers were ovariectomized between 26 and 28 August 1981. Oestradiol implants were inserted on 11 September $1981\left(^{*}\right)$, and experimental lighting began 25 September $1981(\downarrow)$. Note logarithmic scale for prolactin values.

$L H$. Neither $\mathrm{LH}$ pulse frequency nor pulse duration were affected by photoperiod, nor was there a photoperiod $\times$ time interaction (data not presented); however, heifers exposed to natural photoperiod had pulses of greater amplitude $(1.01 \pm 0.16$ vs $0.63 \pm 0.14 \mathrm{ng} / \mathrm{ml})(P=0.08)$ as well as an increased baseline $(1.74 \pm 0.13$ vs $0.54 \pm 0.08 \mathrm{ng} / \mathrm{ml})(P=0.01$; Figs $3 \mathrm{a}, \mathrm{b})$. There was a photoperiod $\times$ time interaction for amplitude for LH pulses $(P=0.01)$ and baseline LH concentrations $(P=0.06)$. 

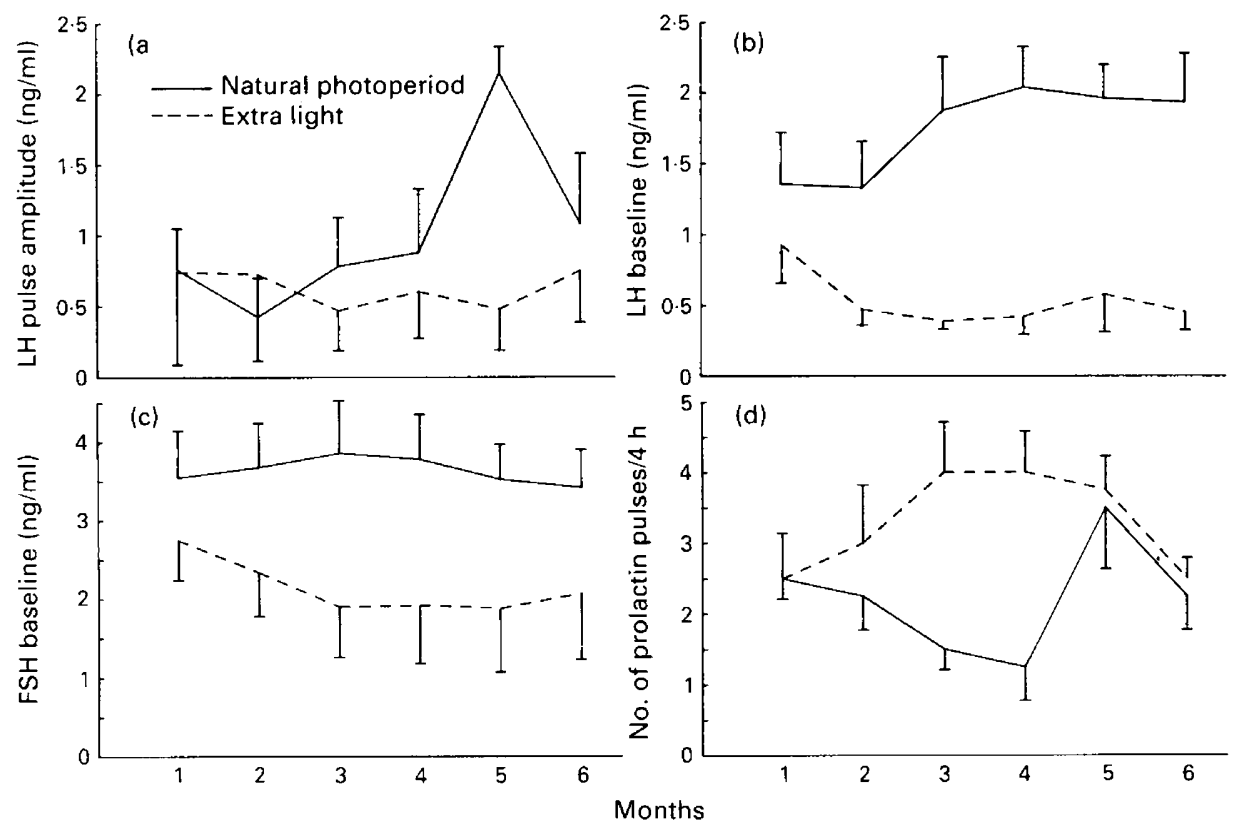

(d)

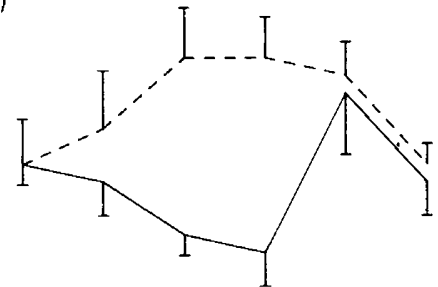

Fig. 3. Effect of photoperiod on mean ( \pm s.e.m.) circulating (a) LH pulse amplitude, (b) LH baseline, (c) FSH baseline and (d) prolactin pulse frequency for heifers exposed to the natural photoperiod $(-)$ or extra light $(--)$. Frequent samples were taken each month from October 1981 to March 1982 (Months 1-6).

FSH. Pulses generally occurred at frequencies of less than 1 per $4 \mathrm{~h}$. At each of the 6 sampling periods (October-March) fewer than half the animals had a single pulse in the 4-h sampling period. Therefore, pulse frequency, amplitude and duration could not be estimated. Heifers in natural photoperiod had higher basal FSH concentrations than those receiving extra light $(3.63 \pm 0.20 \mathrm{vs}$ $2.14 \pm 0.26 \mathrm{ng} / \mathrm{ml})(P=0.05)$ and there was a photoperiod $\times$ time interaction $(P=0.05)$ with FSH concentrations diverging as photoperiod diverged (Fig. 3c).

Prolactin. Prolactin pulse amplitude, duration and baseline were not significantly affected by photoperiod nor were there significant interactions (data not presented). Heifers exposed to extra light had more frequent prolactin pulses than did heifers exposed to natural photoperiod $(3.29 \pm 0.25$ vs $2.20 \pm 0.24$ pulses $/ 4 \mathrm{~h})(P=0.03)$ and there was a photoperiod $\times$ time interaction $(P=0.06)$ with pulse frequencies of prolactin beginning and ending similarly, and following the diverging photoperiod pattern (Fig. 3d).

Temporal relationship between $\mathrm{LH}$ and prolactin. As shown in Fig. 1, in samples taken at 15-min intervals the pooled correlation coefficients were negative for natural photoperiod $(r=-0 \cdot 12)$ and positive $(r=+0.05)$ for the heifers with extra light $(P=0.06)$. There was a photoperiod $\times$ time interaction $(P=0.002)$ with values negative in natural photoperiod and positive in extra light for the first 4 cannulations, and positive in natural photoperiod and negative in extra light for the last 2 cannulations. When photoperiod was decreasing, the correlation was negative and when photoperiod was increasing the correlation was positive. 


\section{Discussion}

Serum LH and FSH concentrations were greater in ovariectomized-oestradiol-treated heifers exposed to a short photoperiod than in those exposed to a long photoperiod. Serum prolactin concentrations were greater in heifers receiving extra light. These results support the hypothesis that photoperiod causes seasonal changes in serum concentrations of gonadotrophins and prolactin in cattle. Previous reports (LaCroix et al., 1977; Peters \& Tucker, 1978; Tucker, 1982) have indicated that prolactin increases with increasing photoperiod in cattle, and that an interaction between ambient temperature and photoperiod may regulate serum prolactin concentrations, with low temperatures causing a decrease in prolactin. An increase in circulating concentrations of prolactin with increasing photoperiod was observed in this experiment during winter. However, there was a main effect of time for both $\mathrm{LH}$ and prolactin, indicating that influences other than photoperiod, possibly temperature, affected the secretion of these hormones. Prolactin pulses were more frequent during long than during short photoperiods. Secretion of prolactin is affected by stress (Rand et al., 1971), time of day (Koprowski et al., 1972) as well as season (Schams \& Reinhardt, 1974) and photoperiod (Peters \& Tucker, 1978). In this study prolactin pulse frequency but not amplitude or duration was affected by photoperiod.

Increased circulating concentrations of $\mathrm{LH}$ during a short photoperiod are consistent with a previous report on ovariectomized-oestradiol-treated heifers sampled over naturally occurring seasons (Critser et al., 1983). The administration of oestradiol by Silastic subcutaneous implant (Day et al., 1984) or by injection (Schillo et al., 1983a; Kamwanja, 1984) initially suppresses LH and FSH concentrations (Hansen et al., 1982) in prepubertal ovariectomized heifers. However, oestradiol administered as subcutaneous implants (Kinder et al., 1983; Critser et al., 1983) or injected (Schillo et al., 1983a) increased LH concentrations in postpubertal ovariectomized heifers. These observations may indicate a reciprocal effect of photoperiod or photoperiodically regulated steroid feedback in immature and postpubertal heifers. This concept is further supported by reports indicating that a long photoperiod hastens attainment of puberty in heifers (Schillo et al., 1983b; Hansen et al., 1983).

Circulating concentrations of $\mathrm{LH}$ and FSH estimated from the weekly samples began to diverge about 4-5 weeks after the initiation of photoperiodic treatment and continued to differ during the rest of the experiment. Concentrations of FSH but not LH began to converge towards the end of the experiment as photoperiod treatments converged. This observation may indicate that (1) mechanisms regulating the secretion of $\mathrm{FSH}$ are more photosensitive than those regulating $\mathrm{LH}$ secretion and that (2) there is a lag between an experimentally produced change in photoperiod and the resulting change in reproductive response in cattle, as has been reported for sheep (Legan \& Karsch, 1980). However, these observations suggest that cattle apparently do not become photorefractory as has been reported for sheep (Robinson \& Karsch, 1984).

Since gonadotrophins have been shown to be released in an episodic pattern (Rahe et al., 1980; Schallenberger \& Peterson, 1982; Walters \& Schallenberger, 1984; Walters et al., 1984), it was anticipated that photoperiod would alter pulse frequency, pulse amplitude, pulse duration and basal concentrations of serum gonadotrophins. Basal concentrations of LH and FSH in samples taken at 15-min intervals diverged initially as photoperiod diverged and remained divergent. Again, as shown by the weekly samples, basal FSH concentrations but not basal LH concentrations began to converge towards the end of the experiment as photoperiod treatments converged. These similarities between the patterns of LH and FSH concentrations in weekly and 15-min samples suggest that photoperiodic alterations in basal secretion of LH and FSH may be primarily responsible for the changes observed at weekly intervals. LH pulse amplitude increased with short photoperiod; however, $50 \%$ or fewer of the animals in either treatment or each monthly 4-h period had more than a single FSH pulse. These results are in contrast to reports which indicated a very high positive correlation between LH and FSH pulses (Schams et al., 1978; Schallenberger et al., 1984; Walters et al., 1984). This difference may have been due to the use of different FSH radioimmunoassays. Some 
FSH radioimmunoassays in current use have been reported to cross-react with LH (Butler et al., 1983), which would cause circulating concentrations of LH to contribute to the estimated FSH concentrations and therefore could cause LH pulses to be perceived as FSH pulses. The existence of a relatively high pulsatile frequency in circulating $\mathrm{LH}$ coincident with a relatively low pulse frequency in circulating FSH in ovariectomized-oestradiol-treated animals was perhaps due to the replacement of oestradiol, which may be primarily responsible for LH regulation; while progesterone or inhibin, which may be primarily responsible for FSH regulation, were not replaced (Miller et al., 1978; Ireland \& Roche, 1982; Walters et al., 1984). Similarly, McNatty et al. (1984), using intact cows, have reported lower $\mathrm{LH}$ pulse frequencies in autumn and winter than in spring, with no changes in LH pulse amplitude. This decrease in LH pulse frequency during autumn and winter was associated with an increase in circulating concentrations of progesterone. These authors suggest that the decrease in LH pulse frequency may be due to the elevated progesterone concentrations, because progesterone, in the presence of oestradiol, has been demonstrated to inhibit $\mathrm{LH}$ pulse frequency in the ewe (Goodman et al., 1981). Similarly, the change in LH pulse amplitude observed in our study with ovariectomized-oestradiol-treated heifers, but not in that of McNatty et al. (1984), may be due to an inhibition of LH pulse amplitude by oestradiol as suggested for the ewe (Goodman et al., 1981).

During the 5 th month there was a marked increase in both $\mathrm{LH}$ pulse amplitude and prolactin pulse frequency among animals exposed to natural photoperiod. At this time there was a positive correlation between $\mathrm{LH}$ and prolactin concentrations in this group.

The similarity between the increase in LH pulse amplitude and prolactin pulse frequency may be a result of a photoperiodically regulated change in the relationship of $\mathrm{LH}$ and prolactin secretion. It has been observed that prolactin and $\mathrm{LH}$ are released reciprocally and a mechanism has been proposed for the concomitant release of gonadotrophin-releasing hormone and prolactin-inhibiting factor by the hypothalamus in response to dopamine (Kamberi et al., 1971; Thorner, 1978; Lamming, 1978). Walters et al. (1984) have reported pulsatile patterns of prolactin release in cows which were highly variable and not consistently associated with gonadotrophin pulses. Examination of the correlation between $\mathrm{LH}$ and prolactin concentrations in samples taken at 15-min intervals indicated a negative correlation when animals were exposed to decreasing photoperiod and positive when exposed to increasing photoperiod. This observation is in contrast with the hypothesis proposed by Kamberi et al. (1971), as their model would predict a negative relationship between LH and prolactin at all times. The changes in sign of the $\mathrm{LH}$-prolactin correlations with changes in photoperiod indicate that one or more photoperiodically regulated factors such as serotonin or melatonin may be involved in this relationship. A model incorporating a prolactin-releasing factor may explain this phenomenon.

The research was supported by the College of Agricultural and Life Sciences. We thank Dr G. D. Niswender for the LH antiserum; Dr L. Reichert for the LH used for iodination; Dr D. J. Bolt and the USDA for donation of FSH and prolactin standards and antisera; the National Institute of Arthritis, Metabolism and Digestive Diseases for LH standards; Dr O. D. Sherwood for donation of oestradiol-17 $\beta$ antiserum; and J. Busby for preparation of the manuscript.

\section{References}

Baxter, R.C. (1980) Simplified approach to confidence limits in radioimmunoassay. Clin. Chem. 26, 763-765.

Beck, T.W., Smith, V.G., Seguin, B.E. \& Convey, E.M. (1976) Bovine serum LH, GH, and prolactin following chronic implantation of ovarian steroids and subsequent ovariectomy. J. Anim. Sci. 42, 461-468.

Bolt, D.J. \& Rollins, R. (1983) Development and appli- cation of a radioimmunoassay for bovine folliclestimulating hormone. J. Anim. Sci. 56, 146-154.

Bulman, D.C. \& Lamming, G.E. (1978) Milk progesterone levels in relation to conception, repeat breeding and factors influencing acyclicity in dairy cows. J. Reprod. Fert. 54, 447-458.

Butler, W.D., Katz, L.S., Arriola, J., Milvae, R.A. \& Foote, 
R.H. (1983) On the negative feedback regulation of gonadotropins in castrate and intact cattle with comparison of two FSH radioimmunoassays. $J$. Anim. Sci. 56, 919-929.

Cleveland, W.S. (1979) Robust locally weighted regression and smoothing scatterplots. J. Am. Stat. Assoc. 74, 829-836.

Courot, M., Goffaux, M. \& Ortavant, R. (1968) Analyse des variations saisonnieres de la fertilite des bovins dans le jura Francais. Annls Biol. Anim. Biochim. Biophys. 8, 209-216.

Critser, J.K., Miller, K.F., Gunsett, F.C. \& Ginther, O.J. (1983) Seasonal LH profile in ovariectomized cattle. Theriogenology 19, 181-191.

Day, M.L., Imakawa, K., Garcia-Winder, M., Zalesky, D.D., Schanbacher, B.D., Kittok, R.J. \& Kinder, J.E. (1984) Endocrine mechanisms of puberty in heifers, Estradiol negative feedback regulation of luteinizing hormone secretion. Biol. Reprod. 31, 332-341.

Forrest, D.W., Fleeger, J.L., Long, C.R., Sorenson, A.M. \& Harms, P.G. (1980) Effect of exogenous prolactin on peripheral luteinizing hormone levels in ovariectomized cows. Biol. Reprod. 22, 197-201.

Gill, J.L. \& Hafs, H.D. (1971) Analysis of repeated measurements of animals. J. Anim. Sci. 33, 331-336.

Goodman, R.L., Bittman, E.L., Foster, D.L. \& Karsch, F.J. (1981) The endocrine basis of the synergistic suppression of luteinizing hormone by estradiol and progesterone. Endocrinology 109, 1414-1417.

Hansen, P.J. \& Hauser, E.R. (1983) Photoperiodic modulation of the length of the postpartum anestrus and positive feedback actions of estradiol in primiparous and multiparous cows. J. Anim. Sci. 57, 341, Abstr.

Hansen, P.J., Kamwanja, L.A. \& Hauser, E.R. (1982) The effect of photoperiod on serum concentrations of luteinizing and follicle stimulating hormones in prepubertal heifers following ovariectomy and estradiol injection. Theriogenology 18, 551-559.

Hansen, P.J., Kamwanja, L.A. \& Hauser, E.R. (1983) Photoperiod influences age at puberty of heifers. $J$. Anim. Sci. 57, 985-992.

Hauser, E.R. (1984) Seasonal effects on female reproduction in the bovine (Bos taurus) (European breeds). Theriogenology 21, 150-170.

Hawk, H.W., Tyler, W.J. \& Casida, L.E. (1954) Some factors affecting age at puberty in Holstein-Freisian heifers. J. Dairy Sci. 37, 252-258.

Hinshelwood, M.M., Dierschke, D.J. \& Hauser, E.R. (1985) The effect of suckling on the hypothalamicpituitary axis in postpartum beef cows, independent of ovarian secretions. Biol. Reprod. 32, 290-300.

Ireland, J.J. \& Roche, J.F. (1982) Effect of progesterone on basal LH and episodic LH and FSH secretion in heifers. J. Reprod. Fert. 64, 295-302.

Jöhke, T. (1970) Factors affecting plasma prolactin level in the cow and the goat as determined by radioimmunoassay. Endocr. Jap. 71, 393-401.

Kamberi, I.A., Mical, R.S. \& Porter, J.C. (1971) Pituitary portal vessel infusion of hypothalamic extract and release of LH, FSH and prolactin. Endocrinology 88, 1294-1 299.

Kamwanja, L.A. (1984) Regulation of onset of puberty in the bovine female, role of season. Ph.D. thesis, University of Wisconsin.
Kinder, J.E., Garcia-Winder, M., Imakawa, K., Kay, M.L., Zalesky, D.D., D'Occhio, M.L., Kittok, R.J. \& Schanbacher, B.D. (1983) Influence of different estrogen doses on concentrations of serum $\mathrm{LH}$ in acute ovariectomized and chronic ovariectomized cows. J. Anim. Sci. 57 (Suppl. 1), 350, Abstr.

Koprowski, J.S., Tucker, H.A. \& Convey, E.M. (1972) Prolactin and growth hormone circadian periodicity in lactating cows. Proc. Soc. exp. Biol. Med. 140, 1012-1014.

LaCroix, P.A., Ravault, J.P. \& Pelletier, J. (1977) Plasma prolactin variations in the male calf in relation to age, season and breed. Annls Biol. anim. Biochim. Biophys. 17, 1095-1099.

Lamming, G.E. (1978) Reproduction during lactation. In Control of Ovulation, pp. 335-353. Eds D. B. Crighton, N. B. Haynes, G. R. Foxcroft \& G. E. Lamming. Butterworths, London.

Legan, S.J. \& Karsch, F.J. (1980) Photoperiodic control of seasonal breeding in ewes: modulation of the negative feedback action of estradiol. Biol. Reprod. 32, 1061-1068.

Mares, S.E., Menge A.C., Tyler, W.S. \& Casida, L.E. (1961) Variation in estrous cycles of Holstein-Friesian cattle. J. Dairy Sci. 44, 897-904.

McNatty, K.P., Hudson, N., Gibb, M., Henderson, K.M., Lun, S., Heath, D. \& Montgomery, G.W. (1984) Seasonal differences in ovarian activity in cows. $J$. Endocr. 102, 189-198.

Mercier, E. \& Salisbury, G.W. (1947) Seasonal variation in hours of day light associated with fertility level of cattle under natural breeding conditions. J. Dairy Sci. 30, 747-756.

Merriam, G.R. \& Wachter, K.W. (1982) Algorithms for the study of episodic hormone secretion. Am. J. Physiol. 243, E310-E318.

Miller, K.F., Critser, J.K. \& Ginther, O.J. (1978) Follicular fluid inhibition of ovulation. In Advances in Experimental Medicine and Biology: Ovarian Follicular and Corpus Luteum Function, pp. 417-421. Eds C. P. Channing, J. M. Marsh \& W. A. Sadler. Plenum Press, New York

Niswender, G.D., Reichert, L.E., Midgley, A.R. \& Nalbandov, A.V. (1969) Radioimmunoassay for bovine and ovine luteinizing hormone. Endocrinology 84, 1166-1173.

Ortavant, R., Mauleon, P. \& Thibault, C. (1964) Photoperiodic control of gonadal and hypophyseal activity in domestic animals. Ann. N.Y. Acad. Sci. 177, 157-193.

O'Sullivan, F., Whitney, P., Hinshelwood, M.M. \& Hauser, E.R. (1984) The analysis of repeated measures experiments in endocrinology. J. Anim. Sci. 59, 1070-1079.

Peters, A.R. \& Riley, G.M. (1982) Is the cow a seasonal breeder? Br. vet. J. 138, 533-537.

Peters, R.R. \& Tucker, H.A. (1978) Prolactin and growth hormone responses to photoperiod in heifers. Endocrinology 103, 229-234.

Rahe, C.H., Owens, R.E., Fleeger, J.L., Newton, H.J. \& Harms, P.G. (1980) Patterns of plasma luteinizing hormone in the cyclic cow: dependence upon the period of the cycle. Endocrinology 107, 498-503.

Rajakowski, E. (1960) Seasonal and cyclical variations of the ovarian follicular system in cattle. Proc. 4th Int. Congr. Anim. Reprod \& A.I., The Hague 2, 186-189. 
Rand, H.R., Kiddy, L.A. \& Odell, W.D. (1971) The effect of stress upon the determination of serum prolactin by radioimmunoassay. Proc. Soc. exp. Biol. Med. 136, 689-693.

Rasmussen, D.D. \& Malven, P.V. (1983) Effects of confinement stress on episodic secretion of $\mathrm{LH}$ in ovariectomized sheep. Neuroendocrinology 36, 392396.

Robinson, J.E. \& Karsch, F.J. (1984) Refractoriness to inducive day lengths terminates the breeding season of the Suffolk ewe. Biol. Reprod. 31, 656-663.

Roy, J.H.B., Gillies, C.M., Perfitt, M.W. \& Stobo, I.J.F. (1980) The effect of season of the year and phase of the moon on puberty and on the occurrence of estrus and conception of dairy heifers reared on high planes of nutrition. Anim. Prod. 31, 13-36.

Salisbury, G.W., VanDemark, N.L. \& Lodge, J.R. (1978) Physiology of Reproduction and Artificial Insemination of Cattle, pp. 651-655. Freeman Press, San Francisco.

Schallenberger, E. \& Peterson, A.J. (1982) Effect of ovariectomy on tonic gonadotrophin secretion in cyclic and post-partum dairy cows. J. Reprod. Fert. 64, 47-52.

Schallenberger, E., Schams, D., Bullermann, B. \& Walters, D.L. (1984) Pulsatile secretion of gonadotrophins, ovarian steroids and ovarian oxytocin during prostaglandin-induced regression of the corpus luteum in the cow. J. Reprod. Fert. 71, 493-501.

Schams, D. \& Reinhardt, V. (1974) Influence of the season on plasma prolactin level in cattle from birth to maturity. Hormone Res. 5, 217-226.

Schams, D., Gombe, S., Schallenberger, E., Reinhardt, V. \& Claus, R. (1978) Relationships between short-term variations of $\mathrm{LH}, \mathrm{FSH}$, prolactin and testosterone in peripheral plasma of prepubertal bulls. J. Reprod. Fert. 54, 145-148.

Schillo, K.K., Dierschke, D.J. \& Hauser, E.R. (1983a) Estrogen-induced release of luteinizing hormone in prepubertal and postpubertal heifers. Theriogenology 19, 727-738
Schillo, K.K., Hansen, P.J., Kamwanja, L.A., Dierschke, D.J. \& Hauser, E.R. (1983b) Influence of season on sexual development in heifers: age at puberty as related to growth and serum concentrations of gonadotropins, prolactin, thyroxine and progesterone. Biol. Reprod. 28, 329-341.

Sislow, J.G., Gordon, W.L. \& Sherwood, O.D. (1979) Laboratory methods manual for $17 \beta$-estradiol and testosterone radioimmunoassay. Reproductive $\mathrm{Bi}$ ology, University of Illinois, Urbana/Champaign.

Snedecor, G.W. \& Cochran, W.G. (1979) Statistical Methods. Iowa State University Press, Ames.

Thibault, C., Courot, M., Martinet, L., Mauleon, P., du Buisson, F., Ortavant, R., Pelletier, J. \& Signoret, J.P. (1966) Regulation of breeding season and estrous cycles by light and external stimuli in some mammals. J. Anim. Sci. 25, 119-142.

Thorner, M.O. (1978) Hyperprolactinanemia and ovulation. In Control of Ovulation, pp. 397-409. Eds D. B. Crighton, N. B. Haynes, G. R. Foxcroft \& G. E. Lamming. Butterworths, London.

Tucker, H.A. (1982) Seasonality in cattle. Theriogenology 17, 53-59.

Tucker, H.A. \& Oxender, W.B. (1980) Seasonal aspects of reproduction, growth and hormones in cattle and horses. Prog. Reprod. Biol. 5, 115-180.

Walters, D.L. \& Schallenberger, E. (1984) Pulsatile secretion of gonadotrophins, ovarian steroids and ovarian oxytocin during the periovulatory phase of the oestrous cycle in the cow. J. Reprod. Fert. 71, $503-512$

Walters, D.L., Shams, D. \& Schallenberger, F. (1984) Pulsatile secretion of gonadotrophins, ovarian steroids and ovarian oxytocin during the luteal phase of the oestrous cycle in the cow. J. Reprod. Fert. 71, 479-491.

Warnick, A.C. (1955) Factors associated with the interval from parturition to first estrus in beef cattle. J. Anim. Sci. 14, 1003-1010.

Received 15 April 1986 